\title{
THE INTEGRITY OF LEARNING AND THE SEARCH FOR TRUTH
}

\author{
Pádraig Hogan \\ Education Department \\ National University of Ireland, Maynooth
}

\section{InTROduction: The Eclipse of Truth as an EdUCATIONAL IdEAL}

Socrates believed that the search for truth was the highest aspiration of human learning. And by truth he meant something more inclusive than the factual accuracy of propositions about the natural world. Much closer to his heart, and to his ever-renewed practical efforts, was the venturesome question of the truth about the right way to live. Yet, in the course of his encounters with the most accomplished intellects of his age, he came to see, as Plato showed him declaring frankly in the Apology, that there was something enigmatic about this question, something that resisted resolution in conclusive terms. ${ }^{1}$ This is not to deny that there are notable advances made in the lively debates of the early dialogues of Plato, which show Socrates at his philosophical and educational best. But those advances are of a curious and frequently chastening kind. Characteristically, they reveal to participants in the dialogues some undetected biases, often crucial ones, in their own starting points. In doing this, however, they also gradually disclose to the participant (or indeed the reader) who remains alert to the tenor of Socrates' thinking something that is both sobering and challenging. This disclosure is the insight that human efforts to lay hold of truth may yield many advances in redressing misconceptions to which human understanding falls captive, but even the best of such efforts probably cannot escape the boundless plurality of human perspectives. On this account the fruits of an open-ended truthfulness - critical yet generous, wellinformed yet ready to venture anew with others - are probably the most that humans can achieve where the pursuit of learning is concerned. And Socrates added, as a final testament to his fellow Athenians, that practicing this truthfulness in their own lives is the most important activity to which they might give their efforts.

To many minds, perhaps even to Plato's, this considered inconclusiveness raises the disturbing specter of relativism. The philosophical challenge is then classically seen as one of overcoming relativism through establishing some encompassing metaphysical overview that provides secure foundations and orientations for thought and action. It cannot be denied, for instance, that the "Socrates" of the later dialogues of Plato features mainly as a literary device for Plato's own arguments and differs in crucial respects from the Socrates of the early dialogues. In particular, the notion of truth that is canvassed by the "Socrates" of the later dialogues contrasts sharply with one that acknowledges human fallibility and limitation in the sense just described. Indeed in Plato's later works, and especially in the

1. Plato, Apology, trans. Benjamin Jowett, http://classics.mit.edu/Plato/apology.html.

EDUCATIONAL THEORY | Volume 55 | Number 2 | 2005 (C) 2005 Board of Trustees | University of Illinois 
educational provisions of his Republic book II onward, truth has the character of a superior - even a sublime - destination, one arrived at by the philosopher rulers who have received a thorough schooling in Plato's metaphysical doctrines and who are thereby fitted to govern. ${ }^{2}$ Such a metaphysical scheme represents an imaginative attempt on a grand scale to remove from education the kinds of risks and ventures that were central to the practice of Socrates. And in the subsequent history of Western education, many such grand attempts to lay secure hold of truth, and to institutionalize what was thus secured in educational practices, would draw upon Platonist or other metaphysics and serve to further eclipse what was most central to Socrates as educator. These subsequent attempts would largely lack Plato's philosophical imaginativeness. Moreover, they would characteristically join metaphysics with theology as a set of prescriptive doctrines to be enforced and passed on in centers of learning throughout those regions that collectively came to be known as Western Christendom.

More than a few educational consequences followed in the wake of the critiques of metaphysical notions of truth that marked new departures for philosophy in the modern period, most notably the critiques by David Hume and Immanuel Kant. As epistemology rose to the position of influence previously enjoyed by metaphysics, philosophers came to articulate goals such as independence of mind, the rational autonomy of the individual, and the promotion of universal principles of reason as educational aims. In practice, however, such aims invariably became entwined with historical forces that were less than universal in scope, such as the diversity of "isms" that proliferated during the nineteenth century, including liberalism, utilitarianism, socialism, and a plethora of nationalisms. In premodern times, the truth proclaimed by a church and founded on metaphysical grounds served to maintain a certain degree of coherence and uniform order, real or apparent, in educational undertakings. But the rise of rival conceptions of rationality itself, often with their own forceful views of truth, not only undermined the coherence of the older order; it also served over time to undermine any new coherence that might be established in place of the older order.

In light of this history it is not surprising that in our own day a stance of incredulity toward the notion of truth itself has come to prevail in major currents of Western philosophy. This stance, broadly characterized as postmodern, has many variants. Common to most of these, however, is the view that epistemological notions of truth have eventually, and rightfully, followed metaphysical ones in falling on hard times. But what remains curiously foreign to postmodern forms of thinking is that there might be a particular understanding of truth worthy of critical attention. In other words, part of the "postmodern condition" seems to be that the

2. Plato, The Republic, trans. Benjamin Jowett, http://classics.mit.edu/Plato/republic.html.

PÁDRAIG HOGAN is Professor in the Education Department at National University of Ireland Maynooth, Maynooth, Co. Kildare, Ireland; e-mail phogan@nuim.ie. His primary areas of scholarship are philosophy of education, innovations in teaching and learning, quality in educational experience, and historical perspectives on education. 
Socratic idea of truth, which associates it with particular kinds of educational effort, continues to be eclipsed from philosophical view. Accordingly, I would like to open my explorations here with a suggestion that is at once a bold claim and a largely unacknowledged conclusion of most postmodern standpoints: If the search for truth is discarded from the purposes of human learning, then something irreplaceable is undermined from the beginning. To elaborate a little, this position undermines the integrity of learning itself as a worthy and enduring human practice - the heart of the matter is lost. Stated in these bold terms the suggestion may seem controversial; however, I offer it not to arouse controversy, but because it makes explicit at the outset some of the more important claims I am keen to argue. To support these claims I will rely on a combination of historical evidence and philosophical argumentation. This approach is in keeping with a conception of philosophy of education that seeks to take into account adequately education itself as a practice.

In the next section, I will explore the influential attempts of premodern forms of authority to domesticate or otherwise control human learning as a search for truth. I will also argue that efforts to redress such attempts in the era of modernity, from the Enlightenment onward, produced some fine insights but also many unhappy consequences from a practical educational standpoint. Then I will review the skeptical tenor of postmodern currents of thinking in the light of these unhappy consequences. While critique can thrive in a philosophical milieu that is strongly laced with skepticism, practice cannot, so in this discussion my main concern will be to bring critique beyond the confining effects of skepticism and into the domain of educational practice. In the final section of the essay, I will try to recover and articulate a notion of truth that properly acknowledges the inclusive nature of educational effort - namely, as an undertaking where one is enjoined to learn anew with a plurality of others in a way that is both venturesome and critically disciplined.

\section{Colonization and Uniformity in Old AND New Learning}

With the hindsight of history we can easily recognize that throughout the Middle Ages a certain view of learning rose to dominance in Western civilization. To call this a "consecrated" view would be broadly correct, once we recognize that the consecration applied more widely than to the study of theology and philosophy; most significantly, it referred to something that was ordained and enforced by the ecclesiastical authorities who retained control over the vast majority of Europe's centers of learning. This is not to deny that a more personal kind of consecration was vital to the unforced commitments of countless individuals in monasteries and other centers of study throughout Western Christendom, individuals who devoted their lives to sacred or contemplative learning. In the broader context, however, conformity to a unified worldview featured strongly in the prevailing Western stance toward learning until the European Renaissance and Reformation, as did a range of punitive measures to be deployed against scholars, teachers, and students who ventured down unorthodox pathways. ${ }^{3}$

3. James Bowen, A History of Western Education, vol. 2, Civilization of Europe: Sixth to Sixteenth Century (New York: St. Martin's Press, 1979), 432ff. 
The contrast looks striking between such a universe of learning and the kinds of learning that are now pursued in an ever-more-globalized world. This modern world (or postmodern, if you prefer) is characterized by an increasing plurality of interacting or juxtaposed cultures. This plurality runs counter to everything that is understood by the patriarchal uniformity of the Middle Ages, or indeed by more recent forms of patriarchal society. Differing versions of this contrast are presented not just in popular estimations but in much of today's philosophical investigation as well. ${ }^{4}$ Here I will focus on the arguments of one such philosopher who has brought his analysis to bear on education in a particularly critical way: Alasdair MacIntyre. His incisive inquiries into moral philosophy in such works as After Virtue, Whose Justice? Which Rationality? and Three Rival Versions of Moral Enquiry expand into broader critiques of features of contemporary society. ${ }^{5} \mathrm{~A}$ picture of radical plurality emerges in these critiques - one that depicts a widespread but undiagnosed incoherence and fragmentation in prevailing moral outlooks and in the human self-understanding that underlies them. In such a society, MacIntyre observes, the absence of clear and compelling standards of moral judgment affects everything that is humanly important. This absence underlies most of the teaching and learning carried on in colleges and schools, and he contends that it is most pronounced in liberal universities, especially in the study of the humanities. In marked contrast to their forerunners in the medieval university and in the denominational precursors of the liberal university, contemporary students of the humanities are, according to MacIntyre, confronted with "the apparent inconclusiveness of all argument outside the natural sciences." They thus emerge from their formal education with a set of skills, but also with a set of preferences that are largely "prerational" ones. ${ }^{6}$ What MacIntyre is alleging here is the operation of something like a vicious circle of cultural influence. The liberal centers of learning owe no allegiance to a traditional faith or to a canonical body of texts and an approved way of teaching them. They therefore produce the type of fragmentation he is criticizing and are in turn affected by new and even more disparate forms of fragmentation in the larger society.

Few can deny that MacIntyre's characterizations carry substantial force. They may also fail to address adequately the complexities of liberal universities. But that is not what I want to explore here. Rather, I want to emphasize that the suggestive force of his critique might also draw attention away from something equally important: the influences that oppose cultural fragmentation. For while wars of radical pluralism beleaguer the humanities today, both on and off campus, other forms of learning constitute

4. Some notable examples are Charles Taylor, Multiculturalism, ed. Amy Gutmann (Princeton: Princeton University Press, 1994); Seyla Benhabib, Situating the Self: Gender, Community and Postmodernism in Contemporary Ethics (New York: Routledge, 1992); Jean-François Lyotard, The Differend: Phrases in Dispute, trans. Georges Van Den Abbeele (Manchester: Manchester University Press, 1988); and Richard J. Bernstein, The New Constellation: The Ethical-Political Horizons of Modernity/Postmodernity (Cambridge: Polity Press, 1991).

5. See Alasdair MacIntyre, After Virtue: A Study in Moral Theory, 2d ed. (London: Duckworth, 1985); Alasdair MacIntyre, Whose Justice? Which Rationality? (London: Duckworth, 1988); and Alasdair MacIntyre, Three Rival Versions of Moral Enquiry (London: Duckworth, 1990).

6. MacIntyre, Whose Justice? Which Rationality? 400. 
a new uniformity on the rise. The disciplines of commercial, administrative, and communicative power - business studies, law, and information and communication technologies (ICT) - have attained the power and influence that was enjoyed by the "supreme science" of theology in universities during the Middle Ages. That is to say, this confluence of disciplines has displaced the "liberal arts" inherited from the medieval university and now continues to devalue the modern ideal of the liberal university. This latter point is particularly significant, and we shall return to it in a moment.

The point of the medieval comparison I have just drawn comes home to us when we realize that an MBA from a prestigious business school nowadays carries the kind of weight that a master's degree in theology carried during the Middle Ages, or during the era of Renaissance and Reformation known to Erasmus and Martin Luther (and indeed long afterward). Even toward the latter part of the modern era, John Henry Newman complained from Oxford in 1834 that the newly established University of London was laying claim to the title Master of Arts. Newman strongly felt the ancient universities should retain exclusive rights to this title, especially in view of its long association with theological learning. ${ }^{7}$

These reflections help to highlight the point that in recent times some momentous shifts have occurred in the educational priorities of Western civilizations. It is not that the stakes are higher or lower than they were in previous times. Rather, what is to count as the stakes has radically changed. We now see more clearly the significance of suggesting, as I do here, that business disciplines have become the "supreme science" of our day. By business disciplines, let me stress again, I mean not just those of economics and finance. The term refers more broadly to the threefold confluence I sketched previously (business studies, law, and ICT). To avoid ambiguity on this point, some further explanation is called for. The discipline of law in the ancient universities retained many connections with canon law, and this relation had consequences for how the concept of justice came to be elaborated and understood in European history. Nowadays, however, such connections are increasingly forged not between law and theology but between the study of law and the interests of commercial and administrative prowess. Moreover, this same family of interests is the primary force stimulating the incessant developments in the various branches of information and communications technology.

Let us try to understand more precisely the nature of this historic shift. Newman's idea of the university, for all its eloquent elaborations of liberal learning, retained for theology a supreme position and a coordinating purpose. Theology, it might be said, provided some safeguard against the risks of unbounded inquiry and debate. In contrast, the specifically modern idea of the liberal university was championed most notably by Wilhelm von Humbolt and his colleagues through the founding of the University of Berlin in the early nineteenth century. ${ }^{8}$

7. Newman's complaint is reviewed in detail by Fergal McGrath in his historical study The Consecration of Learning (Dublin: Gill and Son, 1964), 63ff.

8. Laetitia Boehm, "Wilhelm von Humboldt (1767-1835) and the University: Idea and Implementation," in Town and Gown: The University in Search of Its Origins, ed. Walter Rüegg (Geneva: CRE-Information, New Series 62, 2d quarter, 1983), 89-105. 
This ideal was vigorously reaffirmed by Karl Jaspers in the aftermath of its ruinous overthrow in central Europe during World War II. ${ }^{9}$ The kind of freedom that Humboldt, as Prussian minister for education, sought to secure for the liberal university underscores the very nature of the risks involved. It also highlights the kind of public trust needed to allow a responsible engagement with such risks. This can be gathered from characteristic declarations such as the following: "The state should not look to the universities for anything that directly concerns its own interests, but should rather cherish a conviction that in fulfilling their real function, they will not only serve its purposes but serve them on an infinitely higher plane. ${ }^{\prime 10}$ In contrast to the patriarchal conceptions of authority that marked premodern times, Humboldt clearly announced a radical educational aspiration of the modern period. We can trace here an emancipatory note that reaches back through Kant's educational writings to Jean-Jacques Rousseau's Émile. What Humboldt said of the interests of the state in declarations such as this, other champions of liberal education said of the interests of the church - or, more precisely, of the different Christian churches, for denominational Christianity had secured enormous institutional powers since the Reformation. In our own day, however, such remarks might be directed toward commercial corporations and the governments that assist them, tacitly or otherwise, in coercing higher learning to travel a path from which Humboldt sought to safeguard it. "Might be directed," that is, if remarks like Humboldt's constituted a significant voice in our own time. The fact that such a position does not hold sway in our own time provides revealing insights into what has befallen education, and not just higher education, in recent decades.

Particularly revealing in this regard is the acquiescent stance of public education itself in forgoing the risks that are central to its own inherent purposes - a stance evident in the international context as we hear increasing demands for public education to serve mercenary interests, rather than ecclesiastical ones as in the past. This mercenary tenor of thought and discourse, and the unprecedented force of the influence it can muster, constitutes the heart of the new uniformity I referred to previously and provides in the present context the same kind of bulwark against risk often provided by theology in the premodern university. This is particularly evident in the world of higher education (as other contributions to this symposium show - see, for example, the essay by Richard Smith) and is least pronounced, though not unknown, in the world of early childhood education. It is as if the corporate state were saying "You can play with as many forms of plurality as you like; you can do battle at length over a politics of difference or issues of identity; but you must deliver the goods that we need, and in sufficient supply and innovative variety to enable us to sustain and better our record of economic advance and to retain the edge on our competitors." Put more candidly, this signifies a credo whose main articles of faith could be thus construed: "We believe that

9. Karl Jaspers, The Idea of the University, trans. H.A.T. Reiche and H. Vanderschmidt, ed. Karl W. Deutsche (London: Peter Owen, 1945).

10. Wilhelm von Humboldt, quoted in William Boyd and Edmund J. King, The History of Western Education (London: Adam and Charles Black, 1966), 336. 
interests in matters cultural, ethnic, or religious should be tolerated, indeed encouraged. We also believe, however, that such interests must be curtailed if they seem to interfere with or put at risk the material interests that sustain us where we are: in positions of power, abreast or ahead of our competitors, furnished with the best intelligence, capable of preemptive measures that will keep trouble at bay." So despite the fact that residents of most Western countries now live amid a pluralism that is historically unknown, they are at another level confronted with a uniformity more widespread, more subtle, and probably more effective than that experienced by the god-fearing inhabitants of a previous age.

Unlike the ecclesiastical authorities of medieval times, who could enthrone and sometimes unseat monarchs and emperors, the more powerful adherents of the credo just sketched are constrained by requirements of democratic forms of government that cannot easily be ignored. The goal for such contemporary authorities thus becomes to orchestrate democracy and control the flow of public funds so that commitments to a mercenary credo are somehow given voluntarily (or at least given). From this perspective education is endowed with a strategic significance similar to that which it held in premodern times but that is in other ways unprecedented. If they worried about such things, the state and corporate industry would see in a vision like that of Humboldt something to fear, much as the older religion feared the challenge of a young Martin Luther. But modern corporate states act without concern about the emergence of such voices, dismissing them as a kind of romanticism or yearning for a mythic past. The reason for this has more than a little to do with a widespread disabling of critique as a force that can "speak the truth to power," and therefore as a force capable of building momentum for historically effective change, not least in the case of practices of public education.

\section{Postmodernism and the Debilitation of Practice}

There is a strong sense today that substantive visions of any kind, not merely the sort of radical vision of a Humboldt or a Luther or a Marx, are no longer convincing - that they have become passé. This conclusion finds forceful expression in Jean-François Lyotard's influential work The Postmodern Condition: A Report on Knowledge, first published in 1979. There Lyotard speaks of the temper of a postmodern age as one of "incredulity" to the entire diversity of grand ideals that inspired commitments and actions on a historic scale from ancient times through the medieval period and extending through the age of modernity itself until recent decades. ${ }^{11}$ How large-scale economic interests and the power-knowledge produced by advanced research increasingly intertwine to become the driving force of government and public administration is explained in the fourteen succinct sections of The Postmodern Condition. Lyotard claimed to discern a pervasive abandonment of traditional conceptions of human learning as a search for truth. What I have called a new credo resembles in important respects the picture drawn by Lyotard. But the "incredulity" he alleged would presumably extend to major credos

11. Jean-François Lyotard, The Postmodern Condition: A Report on Knowledge, trans. Geoff Bennington and Brian Massumi (Manchester: Manchester University Press, 1992), xxiv. 
of all kinds. The mercenary one I have sought to describe, he would more likely characterize as the rise of a new structural force - a key feature of the postmodern condition itself. Certainly this is an attitude that embraces the "risk" of education, but with no clear purpose that gives that risk meaning.

While acknowledging the incisiveness of many of Lyotard's insights, it must be pointed out that his arguments bear a striking similarity to the older views his report consigns to history in one regard: they are themselves universal in scope. Ironically, his arguments, like those of Hegel or Marx, present themselves as a grand theory with exhaustive explanatory power. Human agency features less significantly in such theories than do impersonal social forces. Or, more precisely, human agency achieves significance chiefly by being subsumed by social forces. Equally important, however, is the degree of self-critical consciousness (or of its absence) in such critical theory. It characteristically invites the reader to accept the author's insights but neglects to interrogate many assumptions that underlie the author's own stance.

Where a theory such as Marx's sought to increase the scope for taking radical action in order to change the world, such scope is redefined, and reduced, in Lyotard's work. Permeating Lyotard's stance of a "reporter" on the current state of knowledge is itself a stance - one in which the reporter unobtrusively aligns himself with certain features of what he is reporting and induces the reader to do likewise. At the same time, Lyotard does sometimes advocate the stance of a participant in, not merely an observer of, what he calls "agonistics." This involves advocating a postmodernist outlook, as distinct from analyzing the features of postmodernity or of the "postmodern condition." Lyotard thus explores here, as he does more explicitly in his later writings, a view of action that includes the following elements: the quest for dissent (paralogy); bearing witness to the voicing of incommensurable voices (differends); and the destabilizing of emergent hegemonies or consensual tendencies, as well as the discovery of "new moves" in a game that destabilizes both conformist and consensual tendencies. ${ }^{12}$ Even in relatively critical modernist attempts to provide philosophical justification for a consensus that respects the truth claims of others (see Habermas's work, for instance), Lyotard detected the presence of universalizing forces that deny what he considered claims of a more important kind, namely, claims to difference. So all tendencies toward consensus, he urged, must be continually confronted by the effort "to impart a stronger sense of the unpresentable." ${ }^{\prime 13}$

From a practical educational perspective, Lyotard advocated a stance that emphasizes both a politics of resistance and a politics of difference. The necessity for alert and capable action in both types of politics is an incisive contribution to educational thinking. However, Lyotard did not develop, either in The Postmodern Condition or in his later investigation of incommensurable "discursive genres" and "phrase-regimes" in The Differend, a coherent view of what defensible practices of learning might look like. Nor did he explore how teachers might understand and exercise their responsibility to introduce learners to and sustain their interest

12. Ibid., 65-74; and Lyotard, The Differend, xiii, 157ff.

13. Lyotard, The Postmodern Condition, 81. 
in both newer and older fields of knowledge. It is as if all positive efforts to come to mutual understanding, such as the efforts that teachers must make daily amid an ever-increasing plurality of learners, are somehow disfigured from the start.

Where defensible forms of human teaching and learning are concerned, it is difficult to see how Lyotard's critiques yield anything that attains the coherence of a practice. Practice involves purposeful relations that must be built up in the communities where they are carried out. Moreover, these relations are with people encountered not as abstract entities, nor as voices of the incommensurable or instances of "the unpresentable," but as concrete others: flesh-and-blood individuals who are variously alike and unalike and who make claims on one's self from a diversity, even a great disparity, of standpoints. ${ }^{14}$

The radical skepticism that characterizes Lyotard's view of such notions as truth and meaning is based mainly in his opposition to the universalist associations that such notions carry. And for Lyotard, such universalist associations, whether they are those of a dictator or of a Humboldt or Habermas, are potentially totalitarian. He believed that they obscure, deny, or smother difference. More radically, Lyotard seemed to hold that universalist aspirations necessarily have such unhappy consequences.

Thoughts of a similar kind inform the early writings of Jacques Derrida and Michel Foucault, but these ideas undergo some significant shifts in their later work. In his 1967 book Of Grammatology, for instance, Derrida explained that his philosophical strategy was seeking to accomplish "the deconstruction of all significations that have their source in that of the logos. Particularly the signification of truth. ${ }^{\prime 15}$ In his writings of the late eighties and nineties, however, where Levinas's influence is more pronounced, Derrida repeatedly argues that deconstruction was motivated all along by the search for a kind of truth that inspires an "undesconstructible" idea of justice. This is a justice that always beckons from the future, that cannot be institutionalized, that resists determinate encapsulation, and that cannot therefore be owned and deployed by powerful human interests. His late writings (such as his 1993 book Specters of Marx) explain that this is a search for "what remains irreducible to any deconstruction," though he hesitates to use the word "truth." He also speaks of a "messianic eschatology... a certain experience of the emancipatory promise, an idea of justice - which we distinguish from law or right, or even human rights. ${ }^{16}$ Likewise, in his 1990 address "Force of Law: The 'Mystical Foundations of Authority,"' Derrida speaks repeatedly of the "deconstructability of law (droit)" and the "undeconstructability of justice.."17

14. Seyla Benhabib provides a searching investigation of this issue in Situating the Self, chap. 5 .

15. Jacques Derrida, Of Grammatology, trans. Gayatri Chakravorty Spivak (Baltimore: Johns Hopkins University Press, 1976), 10.

16. Jacques Derrida, Specters of Marx, trans. Peggy Kamuf (New York and London: Routledge, 1994), 59.

17. Jacques Derrida, "Force of Law: The 'Mystical Foundations of Authority,"' in Deconstruction and the Possibility of Justice, eds. Drucilla Cornell, Michel Rosenfeld, and David Gray Carlson (New York and London: Routledge, 1992), 14ff. 
Leaving aside for the moment the practical consequences of such developments in a major thinker's position, it is significant that we find a similar progression in Foucault's work. In a 1977 interview titled "Truth and Power," Foucault insisted that "truth isn't outside power," that each society has its "regime of truth," its "political economy of truth."18 On a related theme, he argued in Discipline and Punish that there is no knowledge that "does not presuppose and constitute power relations," further declaring that

These "power-knowledge relations" are to be analyzed, therefore, not on the basis of a subject of knowledge who is forever free or not free in relation to the power system, but, on the contrary, the subject who knows, the objects to be known and the modalities of knowledge must be regarded as so many effects of these fundamental implications of power-knowledge and their historical transformations. ${ }^{19}$

This seems to suggest that philosophy's claim to be a search for truth - a search that might provide resources for emancipation from oppression - is an illusion. Critics like Nancy Fraser, Charles Taylor, Richard Bernstein, and Jürgen Habermas have faulted Foucault on this score and have pointed out that something like a serious notion of truth-seeking must underlie Foucault's entire project if that project is to be coherent. According to Taylor, for instance, "The Foucauldian notion of power not only requires for its sense the correlative notions of truth and liberation, but even the standard link between them, which makes truth the condition of liberation." ${ }^{20}$

There is a noticeable shift in Foucault's later position, as exemplified in his 1984 essay "What is Enlightenment?" There he speaks of his work as trying "to give new impetus, as far as possible, to the undefined work of freedom...work carried out by ourselves upon ourselves as free beings. ${ }^{\prime 21}$ More explicitly, in an interview shortly before his death in 1984, Foucault sharply distinguished his work (which he regarded as critique) from polemics and insisted that everything of importance turned on this distinction: "I insist on this difference as something essential: a whole morality is at stake, the morality that concerns the search for truth and the relation to the other." ${ }^{\prime 22}$

But let us return now to the issue of how the shifts in the positions articulated by Derrida and Foucault affect practice. Despite the greater philosophical attention now given to such notions, neither author provided anything like a substantial account of what emancipatory forms of practice would look like: for instance, practices of education, of medicine, of law, of religion. This is as true of Foucault's late writings on the "care of the self" as it is of Derrida's late writing on politics and on

18. Michel Foucault, "Truth and Power," in The Foucault Reader, ed. Paul Rabinow (London: Penguin, 1991), 73.

19. Michel Foucault, Discipline and Punish: The Birth of the Prison, trans. Alan Sheridan (New York: Pantheon, 1977), 27-28.

20. Charles Taylor, "Foucault of Freedom and Truth," in Foucault: A Critical Reader, ed. David Hoy (Oxford: Blackwell, 1986), 93.

21. Michel Foucault, "What is Enlightenment?" in The Foucault Reader, ed. Rabinow, 46-47.

22. Michel Foucault "Polemics, Politics and Problemisations: An Interview with Michel Foucault" in The Foucault Reader, ed. Rabinow, 381. 
religion. While Derrida remains abstract in his thinking about "a justice yet to come," Foucault offered a few cautious remarks about educational practice:

For example, with regard to the pedagogical relation - I mean the relation of teaching, that passage from the one who knows the most to the one who knows the least - it is not certain that self-management produces the best results; nothing proves, on the contrary, that that approach isn't a hindrance.... The farthest I would go is to say that perhaps one must not be for consensuality, but one must be against nonconsensuality. ${ }^{23}$

In summary, while Lyotard's insights come at the price of constraining the efforts of practitioners - and in a particular way teachers - to the point of a critiqueinduced incapacity for effective action in their workplaces, the analyses developed by Derrida and Foucault achieve something similar. These approaches are "risky" in that they perform high wire feats without a foundational net — but to what end? Arguably, if Foucault had lived longer, he might have provided something quite original in this connection. His final course at the Collège de France on "truthtelling" provides some intriguing clues - intriguing because of their potential implications if brought to bear on his earlier critiques of disciplinary practices. ${ }^{24}$

At the outset of this investigation, I suggested that if the search for truth is discarded from the purposes of learning, then something irreplaceable is undermined from the start: the integrity of learning itself as a worthy and enduring human undertaking. This abandonment has been associated not only with the economic and social policies of corporate states. In the world of learning itself, most notably in higher learning, it has also been associated with the three writers we have just considered. It might be more accurate to say that this association derives less from their intentions as authors than with the accumulated influence of their writings. Critics such as George Steiner view such influence as having catastrophic consequences for Western inheritances of learning. ${ }^{25}$ But I think such consequences are better understood as a debilitation, or an incapacitation, of educational effort that might otherwise be more promising or indeed fruitful. In any event, it is necessary now to attempt to sketch how such efforts might proceed anew, while remaining mindful of what is to be learned, both positively and negatively, from the consequences of postmodern currents of thinking.

\section{A Lesson from Antiquity: Being Enjoined to Learn Anew}

Much of the critical force of postmodern thinking is directed against the predominance of foundational stances in Western philosophy. And, in its full sense, a foundational stance is one which maintains that philosophical thinking must seek to lay hold of objective truth, bring it to full presence, make it secure, and then draw upon it for the organization and conduct of human affairs. Different currents

23. Michel Foucault, "Politics and Ethics: An Interview" in The Foucault Reader, ed. Rabinow, 378-379.

24. This final series of lectures, delivered in 1984, is the subject of an article by Thomas Flynn, "Foucault as Parrhesiast: His Last Course at the Collège de France," in The Final Foucault, eds. James Bernauer and David Rasmussen (Cambridge: MIT Press, 1994), 101-118. Earlier versions of these lectures were presented at the University of California, Berkeley, in October-November 1983, http://foucault. info/documents/parrhesia. See Michael A. Peters, "The New Prudentialism in Education: Actuarial Rationality and the Entrepreneurial Self," included in this symposium.

25. George Steiner, Real Presences: Is There Anything in What We Say? (London: Faber and Faber, 1989). 
of postmodern thinking discern different versions of this stance in metaphysics and in rationalist epistemology. Here metaphysics is to be understood as the long and varied quest, from Plato's later works onward, for an authoritative and conclusive account of all of reality. And rationalist epistemology is to be understood as that quest of more recent centuries, beginning most notably with Descartes, for stable and certain foundations for all of knowledge. Whether Plato can rightly be regarded as the author of the "logocentric" or "teleological" conceptions of truth that Derrida and others have attacked in Western philosophy remains open to question, though the ancestry of such conceptions is usually traced to Plato's later works. ${ }^{26}$ It can scarcely be denied, however, that such conceptions of truth - their paternalistic cast and their strong emphasis on uniformity - have dominated the history of Western education, as distinct from Western philosophy, at least until recent times. Nor can it be denied (although this point is only rarely acknowledged) that this very dominance eclipsed a more ancient conception of truth. Viewed critically, the history of Western education can largely be seen as a history of the effects of this eclipse, especially its replacement by conceptions of truth that were first metaphysical and later epistemological in character. Curiously, neither the postmodern thinking of Lyotard, Derrida, or Foucault, nor the antimodern thinking of MacIntyre, seem to notice the historical fact of this eclipse or, more particularly, to acknowledge the kind of thinking about truth that it obscured. As briefly intimated in the opening pages of this essay, this understanding of truth was nonfoundational and self-critical in character, had no need for distinctions between theory and practice, and was most significant as a form of educational action.

This conception of truth lies at the heart of the lifework of Socrates (469$399 \mathrm{BC}$ ), but earlier traces of it can also be found in the verse of Xenophanes (570$475 \mathrm{BC}$ ) and in some of the enigmatic fragments of Heraclitus (ca. 540-ca. $480 \mathrm{BC}$ ). Its nonfoundational character is quietly disclosed in the curious inconclusiveness that characterizes some early Platonic dialogues, such as Gorgias, Protagoras, Euthyphro, and book I of the Republic. ${ }^{27}$ The Socrates depicted in these dialogues has not yet become a literary device for Plato's own arguments and most likely resembles the real historical Socrates. ${ }^{28}$ The inconclusiveness referred to here is not a form of indecisiveness. Rather, it is usually a suggestive learning experience, one that challenges conventional outlooks for the purpose of undertaking more perceptive efforts, with some decisive consequences for how purposeful action is to be understood and carried out. In the Euthyphro dialogue, for instance, Socrates gives the self-righteous Euthyphro thought-provoking reasons for reevaluating his plans

26. See, for example, Hans-Georg Gadamer, "Reflections on My Philosophical Journey," in The Philosophy of Hans-Georg Gadamer, ed. Lewis E. Hahn (Chicago and La Salle: Open Court, 1997), esp. 26-40.

27. These early dialogues are included in Plato, The Dialogues of Plato, vol. 1, trans. Benjamin Jowett (New York: Random House, 1937). They are also available on the Web at http://www.classics.mit. edu/Plato.

28. Gregory Vlastos draws the contrast between the practical-educational Socrates of the early dialogues and the more metaphysical-theoretical Socrates of the middle and later dialogues in a particularly clear way in his extensive study, Socrates: Ironist and Moral Philosopher (Cambridge: Cambridge University Press, 1991). 
to prosecute his own father. Euthyphro may not heed these reasons, but they can scarcely be lost on the others present, including now (thanks to the early Plato's literary accomplishment) the reader. In the Protagoras dialogue, the Sophist Protagoras comes to realize that his exchange with Socrates has given him reason to reconsider some of his confidently held assumptions about a range of espoused virtues, and to examine what is really involved in his profession of them. In the Gorgias dialogue, Gorgias becomes similarly enlightened regarding the purposes and practice of rhetoric. Equally important, the case of the petulant Callicles in this dialogue is an instructive depiction of the consequences of refusing to engage in the kind of self-criticism practiced and advocated by Socrates. And in book I of the Republic, the youthful Glaucon and Adeimantus gradually gain an educated sense of their own ignorance as they explore the notion of justice with Socrates. They also learn what the consequences of an uneducated ignorance might be, as they witness the embarrassing pitfalls into which an assertive sense of certainty leads Thrasymachus.

But it is in his testimony to 501 fellow Athenians while on trial for his life that Socrates made explicit the kind of insights that informed his own understanding of the highest truth to which human learning might aspire: the truth about the human condition and about how human life might most worthily be lived. During this testimony, recounted in the Apology, he declared,

Real wisdom is the property of God and this oracle is his way of telling us that human wisdom has little or no value. It seems to me that he is not referring literally to Socrates, but has merely taken my name as an example, as if he would say to us "The wisest of you is he who has realised, like Socrates, that in respect of wisdom he is really worthless." ${ }^{29}$

Socrates' account emphasized that limitation and fallibility are inescapable features of human efforts to understand the highest truth to which we can aspire: truth about humans themselves, their experienced world, and the significance of their own place in it. Thus, even at its best, human understanding is limited, and the most it can achieve is a better or worse perspective on the truth. To claim to have reached the truth, or to be in possession of it, would be to claim to have arrived at some kind of superhuman destination and to have left behind the ever-renewed journeying that characterizes educational encounters like those in which Socrates engaged throughout his adult life. To acknowledge all of this is to acknowledge that human learning is probably most promisingly conceived of as a jointly undertaken search. This search involves an interplay with perspectives and horizons of understanding that are sometimes disconcerting, calling into question what one has already understood and made one's own. The search is warranted by the kind of insight Socrates attributed to the oracle at Delphi. It is also kept in check, however, by an awareness of human fallibility and limitation that prevents our aspirations from becoming unrestrained pretensions to mastery, to certainty, to absolute knowledge, or to the final truth.

29. Plato, Apology, in The Last Days of Socrates, trans. Hugh Trendennick (London: Penguin Books, 1993), 23a-b. 
Engaging with the plurality of such horizons, finding oneself challenged by the otherness of perspectives previously unthought of, is to find oneself frequently away from the ontological comforts of home. This can of course engender an adversarial ethos in one's relations with others, and in a particularly turbulent way if one is a teacher. But this is much more likely to occur if one proceeds from something like an unyielding belief in the superiority of one's own view or from a belief that anything less than certainty is a deficiency. Engaging with radical plurality also has the potential to promote the kind of fragmentation about which MacIntyre complains, but this is more likely where such engagement is seen from the start as a form of doing battle rather than as a form of action that combines attentive listening with self-critical reflection and generous but critical response. To engage in such interplays in a fruitful and sustained way, moreover, as teachers must on a regular basis, is to live with risk. It is to come to appreciate that human selfunderstanding is itself something of an interplay: a form of continually being addressed by emergent voices, and of being able to learn anew in one's responses to these voices. And the term "voices" here refers to those who address us through inheritances of learning that usually go by names such as history, science, philosophy, poetry, and so on, just as much as to the voices of immediately present human others who make claims on our beliefs and actions of a momentary, an intermittent, or a more enduring character.

Postmodern currents of thinking, as we have seen, emphasize the point that distortions, hegemonies, and the hidden influence of violence lurk continually in such voices. So pervasive are these dangers, they maintain, that the strongest practical note in many postmodern stances is one that announces the necessity for the strictest vigilance - an attitude of continual resistance. But apart from the incapacity for action that this skeptical watchfulness can induce, vigilance of such a strict kind can itself become a hegemony that beclouds even as it discloses. For instance, Lyotard seemed to suggest that Wilhelm von Humboldt's neglect of this necessity gives reason now for discarding the educational ideals Humboldt sought to promote. ${ }^{30}$ While it is appropriate to address the shortcomings in Humboldt's thinking, Lyotard's critique obscures the heart of his ideals of liberal learning, including the practical necessity for a more reflexive kind of criticism in the pursuit of such ideals.

That reflexive necessity, which also receives insufficient attention in MacIntyre's often combative stances, is already embodied in much of the educational work of Socrates, although one has to read the relevant early dialogues from an educational as well as a philosophical perspective to bring it to explicit awareness. It is the insight that to understand the significance of human learning as a search for truth, including its limitations and its promise, is to be enjoined to practice that search with others in a way that acknowledges and respects the plurality of perspectives. But more than this, it is to begin to share the conviction that there is an emergent kind of universality in the faithful practice of this search for truth. This

30. See Lyotard, The Postmodern Condition, 32-33. 
is properly viewed as an orientation toward universality, but not as seeking consensus. It is rather the twofold acknowledgement (1) that all human understanding is victim to the limitations of perspective, including our own preconceptions and prejudices, and, arising from this, (2) that the most promising stance toward learning lies in the readiness to try, in particular practical instances, to reason from another's point of view as well as from one's own.

Such efforts will of course be attended by misunderstandings and failures, by pitfalls and acrimonies, just as they might also be attended by the detection of previous errors and the disclosure of fresh insights. As Socrates rightly saw, they are unfinishing and unfinishable efforts that have little to do with winning and losing or with having the last word. On the contrary, defensible educational efforts have everything to do with a joint renewal of attentive listening and with the readiness to take risks for defensible learning. In fact, from an educational point of view (and the popular perception of Socrates as a rhetorical combatant obscures this), each of the early Socratic dialogues can be seen as just such an attempt to learn anew in the company of others. Understanding - of oneself, of others, of an issue at stake - might thus be bettered if one remains open to criticism and revision and without laying claim to any final mastery.

The universality in question here is therefore provisional. It arises not from any doctrine or decree, nor from any form of a priori philosophy, but from what can be sustained, to the best of one's uncoerced belief, by the practice of active engagement with differences. This is distinct from Lyotard's "bearing witness to differends," which has a stronger adversarial accent. Where educational practice is concerned, its orientation toward universality must include engaging critically and generously with (1) differences that come to light in one's encounters with students, fellow teachers, parents, and others; (2) differences that come to light in responding to particular inheritances of learning; and (3) differences that come to light in one's understanding of one's own beliefs and outlooks. The forms of practice indicated here for teaching and learning are more suggestive than prescriptive, though not lacking in conviction on that account. They are practices not so much of "living dangerously," as Nietzsche might put it, but ones that acknowledge the ever-present risks and dangers that accompany living without endeavoring to domesticate the search for truth. Such forms of practice seek to be inclusive in scope, exploratory and self-critical in tenor, and fundamentally participatory in character.

\section{CONCLUSION}

It would take more than a few pages to elucidate this suggestiveness, and to illustrate how it brings before us the heart of the matter that constitutes the integrity of education as a human undertaking. Still, a few of its central attributes can be summarized by way of conclusion. First, an incisive awareness of the limitations and possibilities of human understanding itself distinguishes an educational perspective from countless other standpoints that view teaching and learning as part of the machinery for advancing particular corporate interests - whether 
political, commercial, religious, or other. Second, an educational perspective necessarily embodies informed yet self-critical convictions about the kinds of practices through which defensible learning might best be advanced. Third, the practice of education as an ever-renewed and unfinishing search for truth restores to truth itself something of its inspirational force - a force that becomes transformed into a kind of oppression whenever philosophy, or any other kind of intellectual effort, seeks to make it its own property. 